\title{
DJEČJA LEKTIRA I NOVI MEDIJI
}

\author{
Marinko Lazzarich ${ }^{1}$, Antonia Čančar ${ }^{2}$ \\ ${ }^{1}$ Učiteljski fakultet, Sveučilište u Rijeci, Hrvatska \\ ${ }^{2}$ Osnovna škola Ivane Brlić-Mažuranić, Virovitica, Hrvatska \\ marinko.lazzarich@uniri.hr; antonia.cancar95@gmail.com
}

Primljeno: 28. 2. 2020.

Kulturu čitanja oblikuje niz individualno i društveno određenih čimbenika koji proizlaze i iz kulturne tradicije neke sredine zbog čega je status knjige neodvojiv od cjelokupnoga vrijednosnoga sustava pojedinoga društva. Učitelj materinskoga jezika ključna je figura u procesu literarnoga sazrijevanja buduće čitateljske publike, a njegova je uloga otežana društvenim promjenama u današnjem "računalnom" svijetu gdje su položaj čitatelja i knjige bitno izmijenjeni u odnosu na ne tako davnu prošlost. Ne možemo u svemu kriviti digitalne medije, pa tako ni za smanjeni interes učenika za čitanje knjiga. U ovom radu raspravljat će se o složenosti obrazovnoga područja, o kulturi čitanja u novonastalom online okruženju te o promjenama koje donosi aktualni predmetni kurikul za Hrvatski jezik. Kritički će se razmotriti prednosti i nedostatci uporabe informacijsko-komunikacijske tehnologije u odgojno-obrazovnome procesu te ponuditi smjernice za funkcionalnu primjenu mrežnih alata i gotovih aplikacija u nastavi Hrvatskoga jezika. Dječje je odrastanje usko povezano s digitalizacijom i društvenim mrežama čiji utjecaj ne mora biti negativan, samo ga treba funkcionalno iskoristiti i usmjeriti pozornost neupitnom potencijalu dobre knjige. Istaknut će se (ne)opravdanost obvezne školske lektire i problem neuvažavanja čitateljskih interesa učenika mlađe školske dobi. U radu će biti ponuđen metodički predložak za interpretaciju lektirnoga naslova uz primjenu kreativnih mrežnih alata.

Ključne riječi: čitanje, digitalni mediji, dječja književnost, LCDS alati, lektira, literarni interesi 


\section{Uvod}

Knjige su donedavno bile glavni izvor znanja, a vrlo često sredstvo zabave i razonode. $U$ današnje vrijeme tiskane knjige bivaju zamijenjene e-knjigama, a djelatnost čitanja surfanjem na internetu. Pojavom novih medija pisana je književnost postala tradicionalni medij (Gabelica, 2012). ${ }^{1}$ Kriza čitanja problem je s kojim se suočavaju mnoge države, a pojedini metodičari (Lučić-Mumlek, 2002; Ott Franolić, 2020) krivca pronalaze u novim medijima. Po njihovu mišljenju knjiga nije više primarni izvor znanja, a djeca sve manje čitaju jer većinu slobodnoga vremena provode pred zaslonima - televizijskim, mobilnim i računalnim.

Tehnološki napredak iz dana u dan mijenja svijet u kojemu živimo pri čemu su promjene uočljive u različitim sferama ljudskoga života (Livazović, 2008). Osim što olakšava svakodnevni život, tehnologija mijenja i način učenja, a uporaba računala i interneta postaje nezaobilazna, stoga ju učitelji i učenici koriste u nastavi i u izvannastavnim aktivnostima. Riječ je o novoj paradigmi obrazovanja (Ljubešić, 2009; Korljan, 2012).

»Tradicionalna kultura učenja postupno se transformira u novu kulturu učenja koja je više usklađena s potrebama novog društva, društva znanja.« (Rodek, 2011, 11)

Nove generacije učenika vrlo dobro prihvaćaju nagle promjene upravo zbog okolnosti u kojima odrastaju.

Implementacija računalne tehnologije u nastavi zahtijeva drugačije načine učenja i poučavanja te pruža raznovrsne mogućnosti organiziranja nastavnoga procesa. Općeprisutna digitalizacija traži od učitelja praćenje novih trendova u obrazovanju, a isto tako i razumijevanje promjena i načina života mlađih generacija. Unatoč tome što je tiskana knjiga »zastarjeli medij«, ona i u digitaliziranom okružju nalazi svoje mjesto (Loh i Sun, 2019) jer čitanje i književnost ne izumiru. ${ }^{2}$ Svakom pojavom novog medija kojega djeca snažno prihvate kod učitelja se javlja strah

${ }^{1}$ Čitatelj tijekom čitanja postaje slušatelj, gledatelj, a ponekad i igrač. Multimedija nadjačava sadržaj čime čitanje prestaje biti središtem čitateljske pažnje, a čitanje online sadržaja sporije je od čitanja teksta iz knjige upravo zbog popratnih animacija (Gabelica, 2012).

2 Istraživanja potvrđuju kako mladi daju prednost otisnutome materijalu u odnosu na čitanje sa zaslona. Nažalost, online navike čitanja odražavaju se na njihov doživljaj papirnatih izdanja (Loh i Sun, 2019). 
da će on potisnuti knjigu (Težak, 1999). Kao posljedica tehnološkoga razvoja nastaju elektronički oblikovani tekstovi koji zahtijevaju drugačiji pristup čitanju, s obzirom da se mijenja način interakcije s tekstom. Digitalni mediji pružaju pak raznovrsne mogućnosti kojima se mogu razviti čitalačke navike. Važno je imati na umu da bi naglasak trebao biti na razvoju učeničkih sposobnosti, a informacijsko-komunikacijska tehnologija (IKT) trebala bi poslužiti kao sredstvo zanimljivijeg načina prenošenja obrazovnih sadržaja. Kvalitetno poučavanje uz primjenu novih medija ostvarivo je ako učitelj ima razvijenu informatičku i informacijsku pismenost o čemu će biti riječi u ovome radu. Nastavnom procesu valja pristupati u skladu s vremenom u kojemu živimo i unapređivati ga korištenjem različitih mrežnih alata. U tom se kontekstu cjeloživotno obrazovanje učitelja u području informacijsko-komunikacijskih tehnologija postavlja kao nužnost. Needucirani učitelji i nastavno osoblje doprinose povećanju generacijskoga jaza između digitalnih urođenika i digitalnih pridošlica (Prensky, 2001) ${ }^{3}$ koji je već odavno prisutan.

Ovim se radom želi skrenuti pozornost na mogućnosti primjene informacijsko-komunikacijske tehnologije u razrednoj nastavi, prvenstveno u području lektire. Raspravljat će se o složenosti predmeta $\mathrm{Hr}-$ vatski jezik i o kulturi čitanja. Bit će ponuđen pregled mrežnih alata i gotovih aplikacija koje je moguće primjenjivati u nastavi, a ponudit ćemo primjer metodičke interpretacije novijega književnoumjetničkoga predloška primjenom LCDS-alata.

\section{Nastava književnosti i kultura čitanja u digitaliziranome dobu}

Hrvatski jezik najsloženiji je predmet u primarnom obrazovanju, no s obzirom na to kako djeca provode svoje slobodno vrijeme, postavlja se pitanje je li fond sati materinskoga jezika dostatan za razvoj kulture čitanja i čitalačke pismenosti. Prvi susret djeteta s knjigom iznimno je značajan, a velik utjecaj na razvoj kulture čitanja imaju roditelji, odgo-

${ }^{3}$ Pripadnike tzv. net generacije koji odrastaju s novim tehnologijama Prensky naziva digitalnim urođenicima (engl. Digital Natives). Nasuprot njima stoje digitalni useljenici ili pridošlice (engl. Digital Immigrants), pripadnici starije generacije koje nije zahvatio takav zamah digitalnoga razvoja (Miloš, 2017). 
jitelji i učitelji. U nastavi književnosti kod učenika valja razviti unutarnju motivaciju kako bi izvannastavno čitanje postalo užitak. Nažalost, istraživanja kanadskog stručnjaka Davida S. Mialla (2006) pokazuju da brojni učenici radije idu stomatologu nego na sat književnosti.

Odabir književnih tekstova u nastavi književnosti mora biti primjeren recepcijskim mogućnostima učenika. Poticanje zanimanja učenika za čitanje u vrijeme krize čitanja postaje sve veći izazov za učitelje (Lazzarich, 2017). Učitelj mora biti spreman na prilagodbu nastave književnosti ako želi odgojiti samostalnog aktivnog čitatelja u suvremeno doba tehnologije koja je postala potreba, a ne izbor pojedinca (Grosman, 2010). Svrha je nastave književnosti u primarnom obrazovanju potaknuti zanimanje učenika za čitanje i razvoj kulture čitanja i u tom kontekstu školska lektira ima svoje opravdanje (Jerkin, 2012). U aktualnom predmetnom kurikulu posebno je naglašena važnost razvijanja čitateljskih navika (Nacionalni okvirni kurikulum, MZOS, 2011). ${ }^{4}$

Kulturu čitanja treba razvijati od prvoga razreda. U sklopu primarnoga obrazovanja najvažniju ulogu uvođenja djece u svijet književnosti ima učitelj, ali i roditelji i odgojitelji koji bi i ranije trebali djecu upoznati s književnošću. ${ }^{5}$ Učenicima mora biti jasno zašto je čitanje važno, a učitelj treba biti svjestan da ne postoji univerzalan način poučavanja svih

${ }^{4}$ Posljednjih su se desetljeća pogledi na obvezan popis lektire i slobodan izbor književnoumjetničkih djela razlikovali i mijenjali. Donedavno je popis naslova za nastavu lektire od prvoga do četvrtoga razreda bio zadan Nastavnim planom i programom (2006). Odlukom o donošenju kurikuluma za nastavni predmet Hrvatski jezik za osnovne škole i gimnazije u Republici Hrvatskoj dolazi do značajnih promjena u izvannastavnome čitanju. Popis djela za cjelovito čitanje sastavljen je prema načelu mogućnosti ostvarivanja odgojno-obrazovnih ishoda u predmetnome području te je prepušten profesionalnoj autonomiji učitelja. Učitelj se pri planiranju i organiziranju nastave može služiti predloženim popisima izbornih književnih djela i ulomaka. Tijekom osnovnoškolskoga obrazovanja učenik u svakoj školskoj godini samostalno čita određeni broj cjelovitih književnih tekstova koje učitelj izabire radi ostvarivanja predviđenih ishoda, dok samostalno čita jedno djelo po vlastitome izboru. Učenici se potiču na čitanje iz užitka radi stvaranja čitateljskih navika i razvijanja čitateljske kulture.

${ }^{5}$ U novije vrijeme u Hrvatskoj bilježimo mnoštvo projekata za poticanje čitanja među mlađom populacijom. Navodimo tek najzanimljivije programe i manifestacije: Ruksak (pun) kulture program je koji su pokrenuli Ministarstvo kulture Republike Hrvatske i Ministarstvo znanosti i obrazovanja; Čitamo mi, u obitelji svi projekt je koji se provodi od 2011. godine s ciljem promicanja čitanja djece i njihovih roditelja; Čitajmo zajedno - čitajmo naglas: zaboravljene knjige projekt je koji se provodi pod pokroviteljstvom Hrvatske udruge školskih knjižničara. Godine 2013. pokrenuta je prva nacionalna kampanja poticanja čitanja naglas djeci pod nazivom Čitaj mi! 
učenika. Sukladno s tim, nastavne metode potrebno je prilagoditi individualnim potrebama učenika (Vizek Vidović et al., 2014). Uloga je učitelja pronaći najdjelotvornije načine kojima će učenike potaknuti na čitanje te im približiti knjigu od rane školske dobi. Zadaća škole je postupno uvoditi knjigu u dječji život i osvijestiti njeno značenje u daljnjem životu djeteta (Lučić-Mumlek, 2002). Važno je stvoriti pozitivno i poticajno školsko okružje koje uvelike ovisi o učiteljevu pristupu prema čitanju. Ako učitelj gaji ljubav prema knjizi i čita iz užitka te navedeno pokazuje i prenosi na učenike, kod učenika se izgrađuju čitateljski interesi, učenici pokazuju zanimanje za određene sadržaje i tematiku, razvijaju kulturu čitanja i stvaraju naviku čitanja. Centner (2007) savjetuje učiteljima izdvajanje više vremena za čitanje s učenicima, kako bi učenici čitanje doživljavali kao slobodnu i radosnu društvenu aktivnost, a ne kao obvezu. Također, preporučuje i slobodan izbor knjiga za čitanje smatrajući da tako učenici ostvaruju veću povezanost s djelom i više uživaju u čitanju.

U digitaliziranome dobu književnost doživljava preobrazbu jer se mijenja medij iz kojega se čita. ${ }^{6}$ Otisnuti književni tekst dobiva svoju inačicu u elektroničkom mediju. Paradoksalno, danas se čita više no ikada, ali ne i književnost. Čitatelj može birati između književnih digitaliziranih tekstova te ostalih tekstualnih i hipertekstualnih oblika.? Učenicima su hipertekstovi privlačniji s obzirom da su popraćeni slikom, videom i zvukom. Unatoč dostupnosti tekstualnih sadržaja, upitna je kvaliteta onoga što se čita. Učenici najčešće čitaju novinske članke, internetske portale, forume, blogove i zabavne tekstove (Stanić i Jelača, 2017; Labaš i Marinčić, 2018). ${ }^{8}$

${ }^{6}$ Čitanje knjiga u tiskanom obliku razlikuje se od čitanja elektroničkih tekstova. Prednosti poput razumijevanja pročitanog, bogaćenja rječnika, asociranja i predviđanja, shvaćanja uzročno-posljedičnih veza samo su neke pogodnosti koje učenici stječu i razvijaju čitanjem knjiga u tiskanom obliku. Navedeni elementi odlike su dubinskoga čitanja koje izostaje čitanjem elektroničkih hipertekstova (Plevnik, 2012).

${ }^{7}$ Hipertekst se kao autorski sustav za prezentaciju sastoji od komponenata namijenjenih autoru i korisnicima. Autoru služi u kreiranju i mijenjanju sadržaja, a korisnicima za čitanje i kretanje po materijalu (Rodek, 2011).

${ }^{8}$ Labaš i Marinčić (2018) istraživali su u kojoj su mjeri masovni mediji zastupljeni u životu djece i kako utječu na njihove stavove. Rezultati istraživanja pokazali su da mediji zauzimaju značajno mjesto u njihovu životu, a mladi ih najviše koriste u zabavne i informativne svrhe, a tek potom u odgojno-obrazovne svrhe. 
Gabelica (2012) smatra kako je potrebno osloboditi se straha od novih medija i pronaći rješenje u kombinaciji tiskanoga i elektronskoga medija. Življenje u doba tehnologije od učitelja zahtijeva praćenje novih trendova u obrazovanju, a isto tako i razumijevanje generacijskih mijena u učeničkoj populaciji. Važno je iznalaziti različite načine motivacije kojima će zainteresirati učenike za obrazovni sadržaj, pritom koristeći sklonost mladih prema digitalnim sadržajima. Digitalni mediji pružaju raznovrsne mogućnosti kojima se mogu razviti čitalačke navike (Gabelica i Težak, 2017). Njihova primjena u nastavi pruža velike mogućnosti organizacije raznih projekata, kao i unutarpredmetne i međupredmetne korelacije. Mnogi metodičari (Jurdana, 2010; Rosandić, 2013; Lazzarich, 2017; Gabelica i Težak, 2017) smatraju kako bi popis lektirnih naslova trebao biti prilagodljiviji te zagovaraju liberalniji pristup u čitalačkoj ponudi iz razloga što se svake godine objavljuje velik broj novih naslova, kako hrvatskih tako i stranih autora.

\subsection{Lektira u razrednoj nastavi $i$ (ne)motiviranost učenika za čitanje}

Nastavni sat lektire razlikuje se od ostalih sati u području književnosti jer je riječ o izvannastavnome čitanju i o procesu koji uključuje izvannastavne bilješke učenika. Učenici samostalno interpretiraju tekstove, izlažu ili odgovaraju na pitanja koristeći se bilješkama te postaju aktivnim sudionicima procesa nastave (Lučić-Mumlek, 2002). Popis lektirnih naslova sačinjen je po antologijskom načelu, stoga su učenicima ponuđeni naslovi iz hrvatske i svjetske književnosti, uglavnom djela neprolazne vrijednosti. Izbor lektirnih naslova vrši se prema kriteriju tematske i žanrovske raznovrsnosti te prema doživljajno-spoznajnim mogućnostima učenika (Rosandić, 2013).

Učitelji se često susreću s problemom motiviranja učenika za čitanje lektirnih djela. Lektira kao najmasovnije čitanje učenicima nije odveć poticajna i nerijetko ih demotivira za čitanje, pogotovo u predmetnoj nastavi. Kao razlozi za nečitanje mogu se navesti nezanimljivost sadržaja i njihova neprimjerenost dobi učenika, jednolični dnevnici čitanja bez diferenciranih zadataka, nemogućnost slobodnog odabira lektirnih naslova, ukalupljen pristup interpretaciji književnih predložaka te nedovoljan broj knjiga u knjižnici. Prevlast digitalnih sadržaja dodatno 
ometa i slabi koncentraciju učenika navikavajući ih na površno »skeniranje« sadržaja (Ott Franolić, 2020). Shodno tomu učenici nerijetko posežu za raznoraznim priručnicima i vodičima za lektiru. Učitelji stoga često provjeravaju čitanost zadanoga naslova (raz)otkrivajući je li se učenik koristio drugim izvorima. Kako bi učitelj otkrio tko od učenika nije pročitao djelo, često postavlja pitanja usmjerena na detalje u knjizi (Vladilo, 2002).

Negativan stav učenika prema lektiri problem je s kojim se suočavaju mnoge države u svijetu. Stručnjaci ističu kako je potrebno svake godine mijenjati i osvježavati popis lektirnih naslova novim djelima te pri tome uzimati u obzir i učeničke književne interese. Također, stručnjaci su usuglašeni i kada je riječ o učeničkom slobodnom izboru lektire te smatraju kako popis lektirnih djela ne bi trebao biti samo učenički odabir zbog nedostatno razvijenih književnih i estetskih kriterija (Saksida, 2005). ${ }^{9}$

Ponekad i učitelji nevoljko pristupaju nastavi lektire jer se suočavaju s izazovom smišljanja motivacijskih postupaka za čitanje. Ukalupljen pristup lektiri i odabir onih djela za koja učitelj već ima gotove pripreme neće djelovati poticajno na učenike i razvoj kulture čitanja (Jerkin, 2012). Odabir istih lektirnih naslova iz godine u godinu uz primjenu jednoličnog modela interpretacije dovodi do prepisivanja bilješki među učenicima i služenja internetom, a osim toga, učenici se lektiri posvećuju samo u jednom navratu (Dujić, 2009). Vranjković (2011) naglašava važnost motivacije koja utječe na stvaranje pozitivnog emocionalnog odnosa prema literarnom tekstu, kao i prema čitanju u nastavne i izvannastavne svrhe.

Nerado čitanje lektire povezuje se i sa suhoparnim ispunjavanjem bilježnice za lektiru čija se forma nije mijenjala desetljećima. Dnevnik čitanja i danas sadržava najosnovnije informacije, poput naslova djela, imena pisca, teme i glavne ideje, karakterizacije glavnih i sporednih likova i pokoje ilustracije.

9 Jerkin (2012) ističe kako je lektira gorući problem našega obrazovnog sustava jer učenici ne vole čitati ponuđene naslove. Mnogobrojna istraživanja upućuju na negativne stavove učenika i učitelja prema lektiri koji su uzrokovani obvezom čitanja, opsežnim brojem naslova, dnevnikom čitanja i ustaljenim načinom obrade lektirnih sadržaja. 
»Teško je reći kome bi se trebalo više diviti - učenicima koji marljivo ispisuju 'plahte' očekivanih odgovora, ili učiteljima koji ih uporno iščitavaju i ocjenjuju.« (Dujić, 2009, 21) ${ }^{10}$

Učitelj mora voditi računa o raznolikosti pisanih zahtjeva kada je riječ o dnevniku čitanja koji se nikako ne bi trebao sastojati od pukog prepričavanja sadržaja djela, ulomka, glavnog događaja, nabrajanja likova, zaokruživanja odgovora, prepisivanja strofe u pjesmi i slično.

»Jednoličnost i neodmjerenost u zahtjevima za samostalno pisanje bilježaka protivnici su nastave lektire.« (Lučić-Mumlek, 2002, 53)

Pri oblikovanju bilježaka učitelj uvijek mora promišljati da ne izazove suprotan učinak jer je temeljni cilj nastave lektire da učenici pronađu zadovoljstvo u čitanju. Cilj dnevnika čitanja u potpunosti je pogrešan ako se upotrebljava samo kao sredstvo provjere pročitanosti djela. Učeničke mape radova primjereniji su način praćenja učeničkog rada i napretka. Uvijek valja težiti kreativnosti u radu i raznovrsnosti metoda kojima će se malim recipijentima približiti književni sadržaj. ${ }^{11}$

\section{Novi mediji u nastavi}

Prema definiciji Svjetske banke, informacijsko-komunikacijska tehnologija (IKT) sastoji se od hardvera, softvera, mreža i medija za skupljanje, pohranjivanje, procesuiranje, prosljeđivanje i prezentaciju informacija (glasovnih, podatkovnih, tekstualnih i slikovnih). Prema Informatičkom rječniku (Kiš, 2006) IKT predstavlja širok spektar suvremenih tehnologija za elektroničku obradu podataka i prijenos podataka na daljinu (Panian et al., 2005, prema Kiš, 2006). Pojam informacijske i komunikacijske tehnologije koja se primjenjuje u odgoju i obrazovanju proizlazi iz pojma informacijske tehnologije, a označava područje

${ }^{10}$ Nedostatan satni fond i poveći broj učenika u razrednim odjelima otežavaju vrednovanje izvannastavnoga čitanja, pa učitelji pribjegavaju dnevniku čitanja kao jednostavnijoj provjeri pročitanosti lektirnoga naslova. Učenici u želji za boljom ocjenom nerijetko pišu ono što učitelj želi pročitati (Vladilo, 2002).

11 Gabelica i Težak ponudile su u knjizi Kreativni pristup lektiri (2017) mnoštvo zanimljivih ideja koje se mogu upotrijebiti u različitim etapama sata lektire. Primjere je moguće prilagoditi s obzirom na odabrano književno djelo, starosnu dob učenika i njihovo predznanje. 
brzih promjena i nagloga rasta (Semenov, 2005). IKT omogućuje »osim slanja i primanja informacija, i aktivan dijalog, raspravu, umrežavanje i formiranje zajednica te konstruiranje znanja« (Vrkić Dimić, 2010, 125).

Budući da je 21. stoljeće razdoblje najbržih i najvećih tehnoloških promjena (Kojčić, 2012), tržište je u području obrazovanja preplavljeno raznovrsnim tehnološkim inovacijama te učitelji ponekad ne mogu uhvatiti korak sa svime što se nudi. Mnoštvo programa, aplikacija i mrežnih alata osmišljeno je s ciljem da nastavu učine zanimljivijom, a učenje lakšim. Odabir nastavnih materijala i sadržaja jednako je važan kao i odabir alata i multimedijskog softvera koji će se koristiti u nastavi. Isto tako, odabir mora biti primjeren ciljevima učenja koje želimo postići, ali i osobinama učenika jer nije svaki medij ili alat primjeren svim dobnim kategorijama učenika ili ciljevima nastave (Matijević, 2000). Važno je kritički promišljati i djelovati kada je riječ o uvođenju novih medija u nastavu. Svjesni činjenice da učenici uživaju koristeći se novim tehnologijama, učitelji moraju biti spremni na modernizaciju nastave. Mogućnosti su raznolike, a najbolje je rješenje kombinacija tradicionalnih i novijih medija. Nikako ne bismo smjeli dopustiti da multimedija nadjačava sadržaj jer je zadaća digitalnih medija učiniti zanimljivijima informacije koje prenose, a implementacija digitalne tehnologije u nastavu ne bi smjela biti sama sebi svrhom.

Izbor nastavnih metoda vrši se s obzirom na sposobnosti učenika, tip nastavnoga sata i osobitosti nastavnoga sadržaja. Nastavni materijali mogu biti obogaćeni vizualnim, auditivnim, audiovizualnim i multimedijalnim sadržajima (Matasić i Dumić, 2012). ${ }^{12}$ Multimedijalnost u nastavi označava primjenu više medija i multimedija u procesu učenja, a interakcija među njima naziva se intermedijalnošću (Rončević, 2011). ${ }^{13}$ Pravilan odabir multimedija u nastavi jednako je važan kao i poštivanje

12 Multimedijalni sadržaji kombiniraju tekst, sliku, zvuk, animaciju i videozapise, a za reprodukciju multimedijalnih zapisa najčešće se koristi multimedijalno računalo. Macromedia Flash i Director, Sony Sound Forge, Microsoft PowerPoint, Adobe Photoshop, Adobe Premiere programi su koji se najčešće koriste za kreiranje multimedijalnih sadržaja koji se zatim prenose računalom, LCD-projektorom, televizijom te dlanovnikom (Korljan, 2012).

13 Termin multimodalnost odnosi se na primanje informacija kroz više osjetila istovremeno: auditivno, vizualno, olfaktivno, osjetilno i dr. (Rodek, 2011). 
načela njihove uporabe. ${ }^{14}$ Individualna obilježja učenika, didaktička organizacija nastave i učenja, ishodi učenja i mediji u nastavi čimbenici su koji oblikuju nastavu i utječu na njezinu uspješnost. Mediji u nastavi promatrani odvojeno od ostalih čimbenika nisu mjerilo učinkovitosti nastave (Matijević i Topolovčan, 2017). ${ }^{15}$

Didaktički trokut uključuje nastavnika, učenika i nastavni sadržaj dok napretkom tehnologije dolazi do promjena u načinu učenja i poučavanja. U poučavanju postaju neophodna tehnička pomagala, tako da didaktički trokut postaje didaktički četverokut. Za kvalitetnu primjenu nastavne tehnologije potreban je prostor. ${ }^{16}$ Navedeni čimbenici: nastavnik, učenik, nastavni sadržaj, nastavna tehnika i prostor, čine didaktički peterokut (Slika 1) (Činko, 2016).

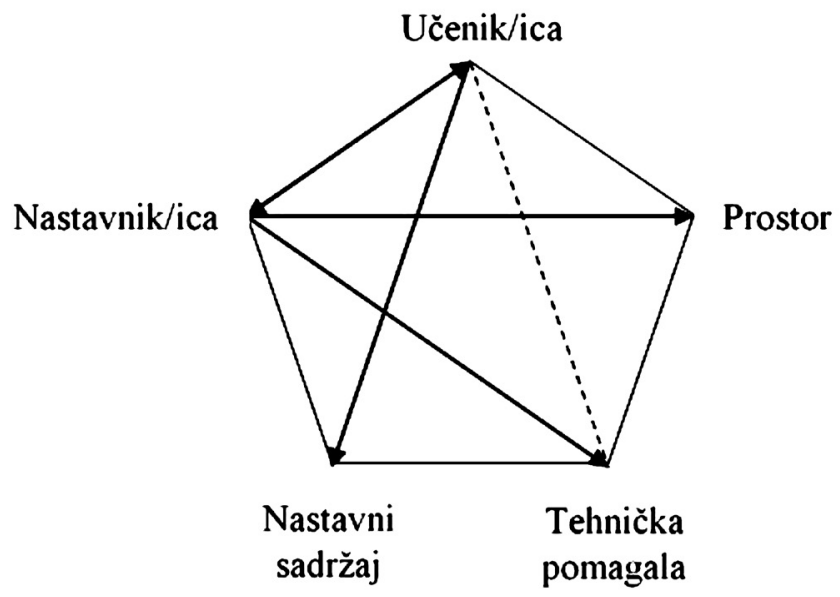

Slika 1. Didaktički peterokut (Činko, 2016,10)

14 Rončević $(2011,82)$ izdvaja sljedeća načela uporabe multimedija u nastavi: »... odmjerenost; uzastopnost i postupnost; pravovremenost; potpunost; ekonomičnost i racionalnost; spretnost; kombiniranost i istinitost."

15 Multimedijska didaktika razlikuje se od drugih didaktika upravo zato što uz aktivnosti učenika i učitelja u nastavnom procesu stavlja naglasak na ulogu svakog medija koji podupire i olakšava proces učenja i poučavanja. Zadaća multimedijske didaktike pojašnjavanje je procesa učenja i poučavanja u okruženju medija (Matasić i Dumić, 2012).

16 U suvremenoj se literaturi spominje i didaktički mnogokut (Meyer, 2005; Pranjić, 2005; Zierer i Seel, 2012). 


\subsection{Prednosti i nedostatci primjene novih medija u nastavi}

Upotreba računala u nastavi može utjecati na poboljšanje školskoga uspjeha učenika, a pristup velikim količinama informacijama brz je i jednostavan (Brčina, 2015). Zagovornici novih medija u nastavi naglašavaju kako oni djeluje motivirajuće na učenike, a učenje i primanje informacija znatno pospješuje multimedijalnost i multimodalnost (Rodek, 2011; Radošević, 2013; Ladan, 2017). Prednosti koje se postižu upotrebom računala $u$ nastavi između ostalih su neposredna povratna informacija za učenika, individualizacija nastave, mogućnost izvođenja simulacija, nastava prilagođena potrebama učenika te primjena raznovrsnih tehnika poučavanja (Vrkić Dimić, 2010). Uporabom IKT nastavni proces postaje dinamičniji i interaktivniji (Sabol, 2016). Uporaba pojedinih web-alata omogućuje brzu povratnu informaciju učenicima nakon rješavanja ispita znanja na računalu (Mikulan, Legac i Siročić, 2011). Rad na računalu ponekad olakšava život djeci s teškoćama u razvoju kojima pisanje i držanje olovke u ruci predstavlja izniman napor. Livazović (2008) ističe kako IKT pospješuje i socijalizaciju djece $\mathrm{s}$ teškoćama u razvoju.

Ipak, odgojno-obrazovne institucije suočavaju se i s poteškoćama pri uvođenju digitalne tehnologije u učionice. Najčešće je riječ o nedostatku financijskih sredstava za implementaciju i održavanje tehnologije, nedostatnome obrazovanju učitelja, nevoljkom pristupanju promjenama, pronalasku balansa između korištenja tehnologije u nastavi i klasičnoga načina poučavanja, a i samo osmišljavanje nastavnoga materijala ponekada zahtijeva mnogo vremena (Radošević, 2013; Krmek, 2017). Tijekom poučavanja digitalna tehnologija može biti ometajući čimbenik u izvođenju nastave jer odvlači pažnju učenika s nastavnoga sadržaja (Rudec, 2004). Računala u informatičkim učionicama katkad su upitne kvalitete, nekompatibilna za pokretanje novijih edukativnih računalnih programa. Brčina (2015) negativne učinke pretjerane uporabe tehnologije nalazi u neprimjerenim sadržajima, izloženosti nasilju i zlostavljanju u školi, ovisnosti o internetu, zapostavljanju umjerene ili jače tjelesne aktivnosti te problemima s vidom i dugotrajnim sjedenjem. Bašić (2020) upućuje na opasnosti pretjeranoga scrollanja po ekranu (a sve manjeg čitanja) zbog čega djeca imaju slabije razvijenu maštu i teže shvaćaju pojmove utemeljene na prenesenome značenju i metafore. La- 
dan (2017) napominje kako negativne učinke ne možemo u potpunosti spriječiti, ali možemo djelovati na način da učenike obrazujemo upravo u području IKT kako bi odgovorno koristili računalo i internet.

Starije generacije učitelja često pokazuju strah i odbojnost prema korištenju računala u nastavi te njihovi učenici nerijetko posjeduju višu razinu informatičke pismenosti od učitelja. Jaz koji je prisutan između digitalnih urođenika i digitalnih pridošlica postat će još veći ako učitelji nisu spremni na promjene koje dolaze (Kojčić, 2012).

\subsection{Mrežni alati u nastavi Hrvatskoga jezika i lektire}

Danas je internet preplavljen mnoštvom računalnih programa, aplikacija i mrežnih alata koji su dostupni svima, a riječ je o Web 2.0 aplikacijama. ${ }^{17}$ Kultura čitanja mladih nedostatno je razvijena jer učenici uglavnom svoje slobodno vrijeme provode pred zaslonima računala ili mobitela. Učitelji se nastoje boriti protiv trenda nečitanja mijenjajući načine poučavanja nastavnoga sadržaja i interpretacije lektire. Uz malo truda, kreativnosti i volje učenicima se svaki lektirni naslov može približiti na drugačiji i zanimljiviji način koristeći se besplatnim i svima dostupnim mrežnim alatima. LCDS (eng. Learning Content Development System) alati pružaju mogućnost izrade materijala, poput kvizova, igara, testova znanja, animacija, radnih listića i raznih aktivnosti koje se mogu upotrijebiti na satu lektire, a isto tako postoji mogućnost primjene u drugim nastavnim predmetima. Potrebno je upoznati učenike s ovakvim načinom interpretacije književnih tekstova te ih uputiti kako se koriste LCDS alati da bi i sami mogli kreirati slične sadržaje. ${ }^{18}$ Primjena IKT u nastavi Hrvatskoga jezika ostvariva je u svim područjima i jezičnim djelatnostima, ali je pritom važno odabrati kvalitetne

17 Termin Web 2.0 u upotrebi je od 2004. godine (Činko, 2016). Primjena Web 2.0 alata unosi svježinu i dinamiku u nastavni proces. Moguće ih je primjenjivati u učionici na različite načine: osim u redovnoj nastavi, mrežni se alati mogu rabiti u izvannastavnim aktivnostima i drugim oblicima rada kao nadopuna nastavi, a njihovo korištenje može doprinijeti razvoju individualnih sposobnosti učenika (Ružić, 2011).

18 Učitelji odabiru najprigodniji alat koji može poslužiti za izradu potrebnih zadataka. Primjena web-alata olakšava prilagodbu sadržaja i materijala učenicima s teškoćama u razvoju, kao i darovitima učenicima (Delić, 2011). LCDS alatima može se pristupiti preko službene mrežne stranice Microsofta ili preko CD-a za one učenike koji nemaju internet u svome domu. 
odgojno-obrazovne sadržaje i alate. ${ }^{19} \mathrm{U}$ nastavku rada bit će ponuđeni primjeri korištenja IKT u nastavi književnosti i lektire.

Pri interpretaciji lektirnih naslova umne mape mogu poslužiti kao svojevrsni sažetak pročitanoga djela. Isto tako, moguće je na kraju školske godine izraditi umnu mapu koja će biti sinteza svih pročitanih lektirnih naslova. Učenici mogu izrađivati umne mape te ih dijeliti s drugima. Neki od navedenih alata pružaju mogućnost spremanja umnih mapa u obliku slikovnih formata koje je moguće i ispisati. Umne se mape uređuju umetanjem raznoraznih vizualnih prikaza, auditivnih i audiovizualnih zapisa i simbola što ih čini vizualno privlačnijima.

Pageplus, Publisher i LetterPop programi su kojima se izrađuju i dizajniraju brošure, letci, razglednice i plakati. Međumrežje nudi mnoštvo jednostavnih računalnih alata, veoma uporabljivih u nastavi, koji učenicima pružaju mogućnost iskazivanja kreativnosti (Blažić, 2010). Nakon pročitanoga lektirnoga naslova, učenici u razredu mogu izraditi zajednički plakat ili brošuru o djelu te ga zalijepiti na vrata učionice ili ga prezentirati susjednome razredu te tako zainteresirati učenike za čitanje lektirnoga djela. ${ }^{20}$ Pixton, Make Beliefs Comix, Strip Generator, BITSTRIPS, Comic Life, StoryboardThat samo su neki od interaktivnih mrežnih alata koji omogućuju izradu stripova. Besplatni su, jednostavni za korištenje, a učenicima vrlo zanimljivi. U nastavi lektire mogu se koristiti tako da se najdraže poglavlje pretvori u strip. Isto je moguće

${ }^{19}$ Mnoštvo je mrežnih alata pomoću kojih učitelji mogu kreirati materijale za nastavu jer su lako dostupni pa ih mogu koristiti učenici i njihovi roditelji. Za njihovu uporabu potrebno je poznavanje engleskoga jezika. Sploder, ClassTools i Gamefroot pogodni su za kreiranje računalnih igara (Kornfeind, 2006; Janko, 2015). Mateljan, Širanović i Šimović (2008) daju prijedlog alata temeljenog na obrascima koji je vrlo pogodan za izradu testova znanja ili nastavnih listića kojima se može provjeriti poznavanje i razumijevanje nastavnih sadržaja ili pročitanosti lektirnoga djela: Qedoc Quiz Maker, Vrući krumpiri (eng. Hot potatoes) primjer je obrazovnoga softvera koji se može koristiti online ili offline. Također je besplatan kao i prije navedeni alati te se može primjenjivati u svim predmetima - isprintano na papiru ili preko LCD-projektora (Milinović i Nemeth-Jajić, 2011).

20 Blažić (2010) navodi primjere mrežnih instrumenata za izradu slikovnica, poput Picture Book Maker, My Storymaker ili crtića Zimmer Twins i Domo Animate. Navedenim se alatima mogu stvarati vlastite priče ili mogu poslužiti u svrhu prepričavanja pročitanoga djela. Prezi je interaktivni web-alat za prezentiranje sadržaja te je odlična zamjena za PowerPoint jer unosi dinamičnost u klasičnu prezentaciju. Tijekom nastave lektire učenici mogu koristiti ovaj alat tako da prepričaju sadržaj književnoumjetničkoga teksta ili jedan ulomak, da u skupini izrade prezentaciju popraćenu govorom, a tijekom izlaganja scenski prikažu radnju djela. Na taj način razvijaju svoju kreativnost. 
učiniti i s izabranom epizodom iz djela ili kratkim prikazom cjelokupne radnje, dakako, ovisno o dužini polaznoga teksta. ${ }^{21}$

Osim mrežnih alata koji učiteljima omogućuju pripremu nastavnih materijala, postoje i gotovi obrazovni softveri, interaktivne edukativne igre, sadržaji, CD-i i portali koji nude pregršt gotovih materijala za razrednu nastavu čiji su kreatori učitelji sami.

\section{Metodički predložak nastavnoga sata lektire}

Navest ćemo primjer interpretacije lektirnoga naslova u 4. razredu, uz primjenu digitalne tehnologije. Kao literarni predložak poslužit će nam dječji roman Pustolovine Arna $i$ Điđija, suvremene hrvatske spisateljice Nade Mihelčić. ${ }^{22}$ Budući da je riječ o opsežnijem književnoumjetničkom tekstu, za realizaciju ove nastavne jedinice potreban je dvosat. Kako je u fokusu ovoga rada metodička funkcionalnost digitalnih sredstava, usredotočit ćemo se na središnju nastavnu etapu - interpretaciju teksta.

Nakon uvodnih dijelova sata, doživljajno-spoznajne motivacije, lokalizacije teksta i interpretativnoga čitanja odabranoga ulomka iz romana te objavljivanja utisaka, učitelj/ica može podijeliti učenike u četiri skupine. Svakoj skupini zadaje drugačiju aktivnost koja je usmjerena na različite segmente djela. Prva skupina pozabavit će se flip book- po-

${ }^{21}$ Pojedini alati nude mnoštvo već gotovih likova i objekata. Pixton je jednostavan alat namijenjen izradi stripova s već unaprijed pripremljenim repozitorijem sadržaja. Idealan je za razradu književnih djela gdje učenici mogu na vizualan način prikazati radnju lektirnoga naslova ili određene epizode, birajući izradu stripa ili lika. Strip je moguće objaviti kako bi bio vidljiv i dostupan ostalim korisnicima (Valčić, 2016). Drugim se alatima objekti i likovi crtaju pokretom računalnog miša. Postoji veliki broj mrežnih programa za crtanje na računalu. Mahom je riječ o profesionalnim programima, poput Edraw Maxa za dizajniranje stambenoga prostora. U nastavi bi se eventualno mogao koristiti program Bojanje $3 D(\mathrm{u}$ sklopu operacijskog sustava Windows10), koji nudi alate za crtanje, bojanje crteža i 3D modeliranje.

22 Nada Mihelčić rođena je 1946. u Zagrebu, gdje se školovala na Fakultetu političkih znanosti. Dugi niz godina radila je u izdavačkom poduzeću »August Cesarec« i tek usputno pisala kratke priče za djecu objavljivane u Modroj lasti. Tek u svojim kasnijim godinama piše prvu radio-dramu za djecu Arno i zlatna ribica te svoj prvi i od čitalačke publike vrlo dobro prihvaćen roman za mlade Bilješke jedne gimnazijalke. Dobitnica je prestižnih nagrada za romane Zeleni pas i Pustolovine Arna i Điđija. Preminula je u Zagrebu 2015. godine. (N. B., 2020). 
kretnim knjižicama. Učenici dobivaju na uvid fotografije s primjerima pokretne knjižice te im je ponuđen materijal za njezinu izradu. Najprije spajaju i lijepe papire kako bi dobili oblik bilježnice. Na prvoj stranici nacrtaju se polja vodoravnom linijom. Polja se imenuju sljedećim redoslijedom: mjesto i vrijeme radnje, likovi, fabula, tema djela i književna vrsta. Nakon pisanja ovih naslova učenici izrezuju papire tako da svako polje postaje zasebna pokretna knjižica.

Druga skupina izrađivat će interaktivne mape likova. Uz promatranje slikovitih modela interaktivnih mapa, učenici dobivaju zadatak da listove papira različitih dužina slože u malu bilježnicu, redajući ih po veličini, od najkraćega prema najdužem listu. Učenici na dnu svakoga lista zapisuju posebnu kategoriju: vanjski opis lika, govor lika, ponašanje lika, pojedinosti i zanimljivosti o liku. Izrađuju interaktivne mape likova Arna i Điđija. Učitelj/ica ih potiče na razmišljanje o osobinama likova koje će po završetku prokomentirati s ostalim učenicima.

Treća skupina poradit će na pripovjednoj stazi koja će nastati na hamer-papiru, dok će četvrta skupina dobiti zadatak pod nazivom 'prozorčići u priču'. Učenici na hameru crtaju stazu koja predstavlja tijek radnje u priči. Na stazu uvrštavaju događaje ili pojmove koji ih podsjećaju na određeni dio priče, a zatim zajedno prepričavaju događaje iz romana. Potrebno je navesti kompoziciju priče, a na kraju zapisati glavnu misao teksta. Ova aktivnost uključuje interaktivnu mapu koja sadrži šest pitanja koja se nalaze s unutarnje strane trokuta. Učenici odgovaraju na pitanja bacanjem kocke. Učitelj/ica može zatražiti da učenici dizajniraju unutrašnjost interaktivne mape, a kasnije mogu odgovarati na pitanja pred ostatkom razreda. Čitavo vrijeme učiteljica obilazi učenike i prati njihov rad po skupinama. Po isteku dogovorenoga vremena slijedi izlaganje predstavnika svake skupine i zapisivanje plana ploče.

U zadnjim dvjema nastavnim etapama slijedi rad na računalu. U sintezi učenici ponavljaju najvažnije elemente iz romana Pustolovine Arna $i$ Điđija. Učenici ostaju u skupinama kako bi radili u programu Hot potatoes. Svaka skupina dobiva različite zadatke koji se odnose na ponavljanje najvažnijih elemenata iz dječjega romana. Prva skupina ispunjava križaljku u alatu JCross (Slika 2, Slika 3) Učenici mogu provjeriti točnost zapisa klikom na »Provjeri« (eng. check). 


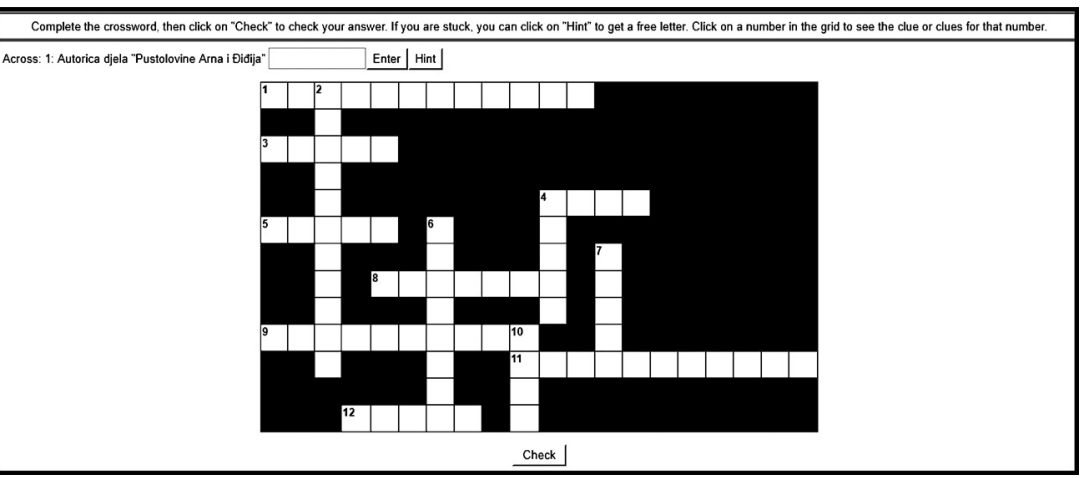

Slika 2. Izgled križaljke u obrazovnom softveru Hot Potatoes - JCross

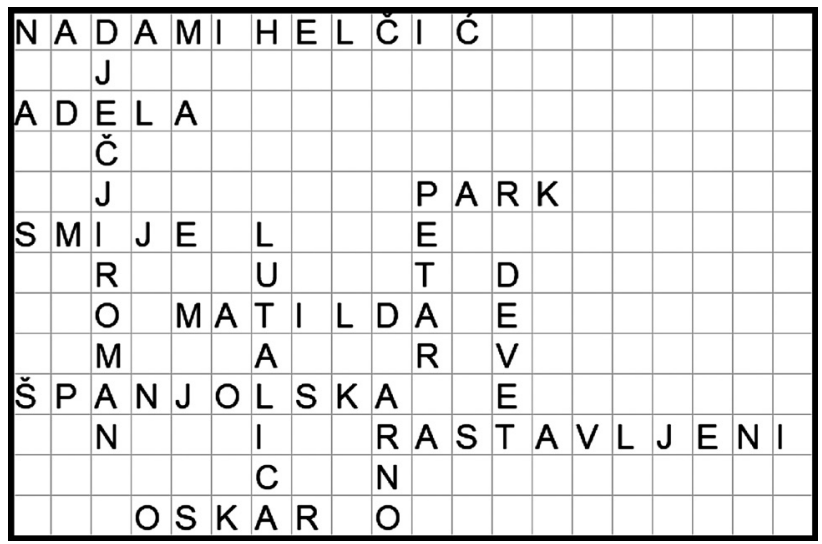

Slika 3. Rješenja križaljke u obrazovnom softveru Hot Potatoes JCross

Druga skupina koristi mrežni alat JQuiz, odgovarajući na pitanja odabirom jednog ili više točnih odgovora ili dopisivanjem onoga što se od njih traži. Učenici treće skupine popunjavaju praznine u potrazi za odgovorima u alatu JCloze. Četvrta skupina od zadanih riječi treba oblikovati rečenice u alatu JMix. Za provjeru točnosti svi mogu kliknuti »Provjeri«. Po isteku vremena slijedi provjera i praćenje točnih odgovora na projekcijskom platnu.

Kao posljednju aktivnost dvosata lektire, učenici u etapi stvaralačkoga izražavanja mogu kreirati strip u jednom od sljedeća dva programa: StoryboardThat ili Pixton (Slika 4, Slika 5). Potrebno je dočarati 
epizodu ili poglavlje iz romana koji su im se najviše svidjeli, a zatim obrazložiti svoj izbor. Prije počeka rada učenicima se pokazuju primjeri i daju upute za izradu stripa u navedenim programima - na koji način funkcionira dijalog u stripu i koliko strip treba biti dugačak. Tijekom izrade stripa učitelj/ica obilazi učenike prateći njihov rad. Po završetku uratci se mogu pogledati na projekcijskome platnu.
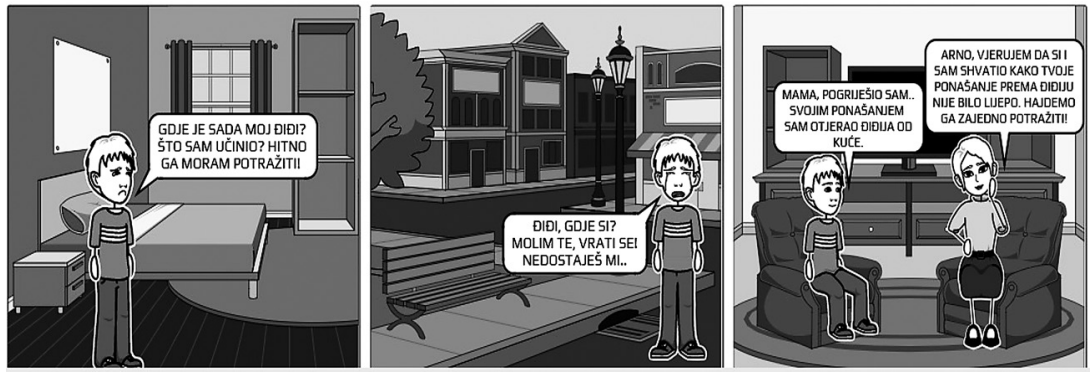

Slika 4. Primjer stripa izrađenog u programu StoryboardThat
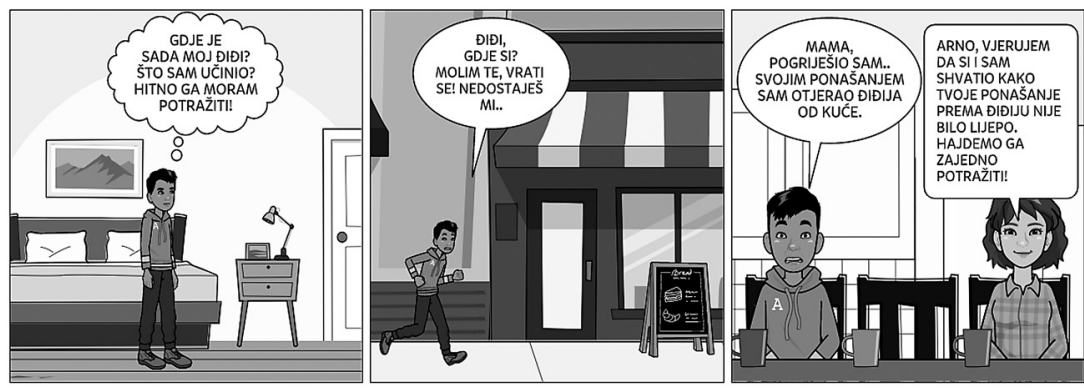

Slika 5. Primjer stripa izrađenog u programu Pixton

\section{Zaključak}

Primarna je uloga učitelja u nastavi književnosti stvaranje pozitivnoga i poticajnoga školskoga ozračja te pronalaženje najdjelotvornijih načina za poticanje učenika na čitanje. Pojava novih medija znatno je otežala ostvarivanje ovih zadaća. Učenici sve manje čitaju, a svoje slobodno vrijeme provode pred raznoraznim zaslonima u online okruženju. Knjige koje su nekoć bile primarni, danas postaju sekundarni izvori znanja. Valja imati na umu da svako vrijeme ima svoj književni izraz (Tadić, 2013). Školska lektira zasigurno nije najomiljenija među 
mlađom populacijom, ali krivca ne treba tražiti isključivo u novim medijima. Digitalni mediji zasigurno nisu jedini razlog nečitanju knjiŽevnoumjetničkih tekstova jer negativnom stavu učenika prema lektiri doprinose i mnogi drugi čimbenici, među kojima i neprimjerenost ponuđenih tekstova recepcijskim mogućnostima učenika. Umjesto da svijet suvremene tehnologije proglasimo neprijateljem pisane riječi, valjalo bi ispitati načine na koje se digitalni mediji mogu koristiti za razvoj čitalačkih navika (Delić, 2020).

Namjera je ovoga rada ukazati na to da razvoj digitalne tehnologije pruža nove mogućnosti organiziranja odgojno-obrazovnog procesa i u području književnosti, kako bi nastava književnosti i lektire bila inovativnija, poticajnija te učenicima zanimljivija.

»Književnost budućnosti bit će književnost po mjeri budućih naraštaja, a nastojanje na zaustavljanju procesa i mijena apsurdno je i nemoguće.« (Tadić, 2013, 136)

IKT omogućuje nove načine učinkovite uporabe digitalnih medija u razrednoj nastavi: besplatni i dostupni web 2.0 alati, aplikacije, mrežni testovi, edukativni softveri i programi pomažu učiteljima u osmišljavanju kreativnih postupaka u nastavi lektire. Uporaba IKT čini nastavu interaktivnijom i dinamičnijom, čime se osuvremenjuje proces učenja i poučavanja. Riječ je o novoj paradigmi obrazovanja koja podrazumijeva i novu kulturu učenja, čega odgojitelji moraju biti svjesni. Kreiranje nastavnoga procesa uz primjenu novih medija kompetencija je koju suvremeni učitelj neminovno treba posjedovati.

Učeničku zainteresiranost za društvene mreže i digitalizaciju treba iskoristiti i usmjeriti njihovu pozornost neupitnom potencijalu dobre literature. Pritom svakako valja uvažavati čitateljske interese učenika mlađe školske dobi. Smatramo da bi pristup čitalačkoj ponudi trebao biti liberalniji jer se svake godine objavljuje velik broj kvalitetnih naslova (kako hrvatskih tako i stranih autora), stoga lektirne popise valja prilagoditi aktualnom trenutku. Kako bismo oprimjerili naznačene teze, ponudili smo metodički model interpretacije književnoga predloška koji zorno svjedoči o edukativnom potencijalu mrežnih alata. Oni pružaju raznovrsne mogućnosti za razvijanje čitalačkih navika, stoga ne treba dvojiti hoće li književno djelo i u digitaliziranom okružju pronaći put do maloga čitatelja. 


\section{Literatura}

Bašić, Anamarija (2020), »Odgoj za medije u hrvatskom obrazovnom sustavu«, Pleter, 4, str. 115-134. doi: https://doi.org/10.51154/p.4.4.6

Blažić, Arjana (2010), Pričam ti priču... digitalnu. Dostupno na: https://pogledkrozprozor.wordpress.com/2010/06/21/pricam-ti-pricu $\%$ e2\%80\%a6-digitalnu/ [5. 7. 2019.]

Centner, Sandra (2007), Kako zavoljeti knjigu i čitanje, Đakovo: Tempo.

Činko, Mateja (2016), Upotreba informacijske i komunikacijske tehnologije u nastavi, diplomski rad, Rijeka: Filozofski fakultet Sveučilišta u Rijeci.

Delić, Iris (2020), Ne, digitalni mediji nisu krivi što u školama ne čitamo lektire. Dostupno na: https://studentski.hr/vijesti/kultura/ne-digitalni-mediji-nisu-krivi-sto-u-skolama-ne-citamo-lektire [23. 6. 2020.]

Delić, Suzana (2011), Primjena LCDS alata u razrednoj nastavi - LEKTIRA. Dostupno na: https://dnevnikuciteljice.wordpress.com/2011/01/07/primjena-1cds-alata-u-razrednoj-nastavi-lektira/ [26. 5. 2019.]

Dujić, Lidija (2009), »Lektira po izboru učenika«, u: Javor, Ranka (ur.), Čitanje obaveza ili užitak, Zagreb: Knjižnice grada Zagreba, str. 21-29.

Gabelica, Marina (2012), »Poticanje čitanja uz nove medije«, Dijete, škola, obitelj, 30(4), str. 2-8.

Gabelica, Marina; Težak, Dubravka (2017), Kreativni pristup lektiri, Zagreb: Učiteljski fakultet Sveučilišta u Zagrebu.

Grosman, Meta (2010), U obranu čitanja. Čitatelj i književnost u 21. stoljeću, Zagreb: Algoritam.

Jerkin, Corinna (2012), »Lektira našeg doba«, Život i škola, 58(27), str. 113-132.

Jurdana, Vjekoslava (2010), »Kako do užitka u čitanju osnovnoškolske lektire?«, Pedagogija, 65(3), str. 462-472.

Kiš, Miroslav (2006), Informatički rječnik: za školu i dom, Rijeka: Andromeda.

Kojčić, Zoran (2012), »Upotreba mobilnih tehnologija u nastavi«, Metodički ogledi, 19(2), str. 101-109.

Korljan, Josipa (2012), »Video u nastavi inojezičnoga hrvatskog«, Zbornik radova Filozofskog fakulteta u Splitu, 5(5), str. 251-262.

Labaš, Danijel; Marinčić, Petra (2018), »Mediji kao sredstvo zabave u očima djece $\ll$, MediAnali, 12(15), str. 1-32.

Lazzarich, Marinko (2017), Metodika Hrvatskoga jezika u razrednoj nastavi, Rijeka: Učiteljski fakultet u Rijeci.

Livazović, Goran (2008), »Primjena računalne tehnologije u odgoju i obrazovanju djece s posebnim potrebama«, Život i škola, 54(19), str. 79-86.

Loh, Chin Ee; Sun, Baoqi (2019), "'I'd still prefer to read the hard copy': Adolescents' print and digital reading habits «, Journal of Adolescent \& Adult Litera$c y$, 62(6), str. 663-672. doi: https://doi.org/10.1002/jaal.904 
Lučić-Mumlek, Kata (2002), Lektira u razrednoj nastavi: metodički priručnik, Zagreb: Školska knjiga.

Matanović, Iva (2017), Upotrebljivost didaktičkih modela u standardizaciji obrazovanja, doktorski rad, Zagreb: Filozofski fakultet Sveučilišta u Zagrebu. Dostupno na: http://darhiv.ffzg.unizg.hr/id/eprint/8565/1/Disertacija Iva Matanovic Upotrebljivost $\% 20$ didaktickih $\% 20$ modela $\% 20 \mathrm{u} \% 20$ standardizaciji\%20obrazovanja_lektorirano.pdf [22.6.2020]

Matasić, Iva; Dumić, Saša (2012), »Multimedijske tehnologije u obrazovanju«, Medijska istraživanja: znanstveno-stručni časopis za novinarstvo i medije, 18(1), str. 143-151.

Matijević, Milan (2000), »Hipermedijska obrazovna tehnologija u osnovnoj školi«, u: Rosić, Vladimir (ur.), Nastavnik i suvremena obrazovna tehnologija, Rijeka: Filozofski fakultet u Rijeci, str. 33-39.

Matijević, Milan; Topolovčan, Tomislav (2017), Multimedijska didaktika, Zagreb: Školska knjiga.

Meyer, Hilbert (2005), Sto je dobra nastava?, Zagreb: Erudita.

Miall, David S. (2006), Literary Reading: Empirical and Theoretical Studies, Bern: Peter Lang Publishing Inc.

Mikulan, Krunoslav; Legac, Vladimir; Siročić, Dunja (2011), »Pozitivni i negativni aspekti platformi za učenje na daljinu Moodle i WebCT u nastavi hrvatskog jezika«, Zbornik radova Međimurskog veleučilišta u Čakovcu, 2(1), str. 83-94.

Milinović, Anđela; Nemeth-Jajić, Jadranka (2011), »Informacijsko-komunikacijske tehnologije u nastavi hrvatskoga jezika«, u: Milat, Josip (ur.), Digital Technologies and New Forms of Learning, Split: Filozofski fakultet Sveučilišta u Splitu, str. 314-321.

Miloš, Irena (2017), »Digitalni urođenici i digitalni pridošlice«, Hrvatski jezik: znanstveno-popularni časopis za kulturu hrvatskoga jezika, 4(2), str. 11-12.

Ministarstvo znanosti, obrazovanja i sporta RH (2011), Nacionalni okvirni kurikulum za predškolski odgoj i obrazovanje te opće obvezno i srednjoškolsko obrazovanje, Zagreb: Ministarstvo znanosti, obrazovanja i sporta RH.

Ministarstvo znanosti, obrazovanja i sporta RH (2006), Nastavni plan i program za osnovnu školu, Zagreb: Ministarstvo znanosti, obrazovanja i sporta RH.

N. B. (2010), Zeleni pas, analiza lektire. Dostupno na: https://www.lektire.hr/zeleni-pas/ [1. 7. 2020.]

Panian, Željko; Klepac, Goran; Knežević, Blaženka; Spremić, Mario; Strugar, Ivan (2005), Englesko-hrvatski informatički enciklopedijski rječnik 1-2, Zagreb: Europapress holding.

Plevnik, Danko (2012), Tolle lege: za slobodu čitanja, Zagreb: Nacionalna i sveučilišna knjižnica.

Pranjić, Marko (2005), Didaktika, Zagreb: Golden marketing - Tehnička knjiga i Hrvatski studiji Sveučilišta u Zagrebu.

Prensky, Marc (2001), »Digital natives, digital immigrants Part 1«, On the Horizon, 9(5), str. 1-6. doi: https://doi.org/10.1108/10748120110424816 
Promo (2019), Lektira treba poticati i čitanje iz užitka. Dostupno na: https://www. tportal.hr/kultura/clanak/lektira-treba-poticati-i-citanje-iz-uzitka-20190705? [23. 6. 2020.]

Rodek, Stjepan (2011), »Novi mediji i nova kultura učenja«, Napredak: časopis za pedagogijsku teoriju i praksu, 152(1), str. 9-28.

Rončević, Anita (2011), Multimediji u nastavi, Split: Redak.

Rosandić, Dragutin (2013), Obrazovni kurikulumi, standardi i kompetencije: s posebnim usmjerenjem na jezično-književno područje, Zagreb: Naklada Ljevak.

Rudec, Tomislav (2004), »Upotreba računala u nastavi u prvim četirima razredima osnovne škole«, Matematika i škola, 28(5), str. 118-122.

Ružić, Ivana (2011), Izrada mentalnih mapa pomoću web 2.0 alata Mindomo. Dostupno na https://pogledkrozprozor.wordpress.com/2011/05/30/izrada-mentalnih-mapa-pomocu-web-2-0-alata-mindomo/ [26. 5. 2019.]

Saksida, Igor (2005), Bralni izzivi mladinske književnosti, Domžale: Izolit.

Semenov, Alexey (2005), Information and Communication Technologies in Schools: A Handbook for Teachers or How ICT Can Create New Open Learning Environments, Paris: UNESCO.

Stanić, Sanja; Jelača, Leon (2017), »Društveni kontekst čitanja knjige: mišljenja i stavovi učenika«, Školski vjesnik, 66(2), str. 180-199.

Tadić, Nina (2013), »Književnost na novim medijima«, u: Mičanović, Miroslav (ur.), Čitanje za školu i život, Zagreb: Agencija za odgoj i obrazovanje, str. 126-137.

Težak, Dubravka (1999), »Utjecaj suvremenih medija na tematske i strukturne promjene u literaturi za mlade«, u: Javor, Rajka (ur.), Mladi i čitanje u multimedijalnom okruženju, Koprivnica: Hrvatsko čitateljsko društvo, str. 41-46.

Valčić, Jelena (2016), »Pixton - Udahnite život u strip«, e-laboratorij. Dostupno na: http://e-laboratorij.carnet.hr/pixton-udahnite-zivot-strip/ [26. 5. 2019.]

Vizek Vidović, Vlasta; Rijavec, Majda; Vlahović-Štetić, Vesna; Miljković, Dubravka (2014), Psihologija obrazovanja, drugo izmijenjeno i dopunjeno izdanje, Zagreb: IEP-Vern.

Vladilo, Ivana (2002), »Lektira - radost čitanja ili tortura«, u: Šušnjić, Biserka, et al. (ur.), Zbornik radova Proljetne škole školskih knjižničara, Novi Vinodolski - Rijeka: Ministarstvo prosvjete i športa Republike Hrvatske, str. 89-94.

Vranjković, Ljiljana (2011), »Lektira u razrednoj nastavi«, Život i škola, 57(25), str. 193-205.

Vrkić Dimić, Jasmina (2010), Utjecaj uporabe računala na praksu učenja i poučavanja, doktorska disertacija, Zagreb: Filozofski fakultet Sveučilišta u Zagrebu.

Zierer, Klaus; Seel, Norbert (2012), General Didactics and Instructional Design: Eyes Like Twins. A Transatlantic Dialogue about Similarities and Differences, about the Past and the Future of Two Sciences of Learning and Teaching. SpringerPlus, 1(15). doi: https://doi.org/10.1186/2193-1801-1-15 


\title{
CHILDREN'S REQUIRED READING AND NEW MEDIA
}

\author{
Marinko Lazzarich, Antonia Čančar
}

The culture of reading is shaped by a number of individually and socially determined factors arising from the cultural tradition of a given environment, making the status of books inseparable from the entire value system of a given society. The teacher of the native tongue is a key figure in the process of literary maturation of the future reading public; the role of the teacher is hindered by social changes in the modern "digital" world, in which the position of the reader and the book are now significantly different than in the recent past. Digital media cannot be solely blamed for the reduced interest of pupils in reading books. This paper will discuss the complexity of the field of education, the culture of reading in the new online environment, and changes brought by the current Croatian language subject curriculum. The advantages and disadvantages of using IT technologies in educational processes will be critically examined; guidelines will also be offered for the functional implementation of internet tools and ready-made applications in Croatian language teaching. Children's upbringing is closely tied to digitalisation and social networks, the influence of which are not necessarily negative; this influence must simply be used functionally to direct attention towards the unquestionable potential of good books. The justification (or lack thereof) for required reading will be noted, as will the problem of disregarding the reading interests of young pupils. The paper will offer a methodical contribution for the interpretation of required reading titles through the implementation of creative online tools.

Key words: reading, digital media, children's literature, LCDS tools, required reading, literary interests 